\title{
Epidemiological aspects of cysticercose in relation to hydrographic net at Triângulo Mineiro, MG, Brazil
}

\section{Aspectos epidemiológicos da cisticercose em relação a rede hidrográfica no Triângulo Mineiro, MG, Brasil}

\author{
Camilla Taveira Ducas Duarte ${ }^{1 *}$; Paulo Sérgio Arruda Pinto ${ }^{2}$; Letícia Ferreira \\ Silva $^{3}$; Tatiane Oliveira Santos ${ }^{3}$; Paula Dias Bevilacqua²; Emílio Campos Acevedo \\ Nieto $^{3}$
}

\begin{abstract}
Cysticercosis affects cattle, which develop the larva of Taenia saginata after ingesting their eggs, which are released by humans. It is a parasite that is distributed worldwide. The use of geoprocessing allows a better definition of endemic areas and populations that face different levels of risk and thus creates a basis for specific control programs for each farming system. The objective of this study was to evaluate the epidemiological situation of bovine cysticercosis in four municipalities in the Triângulo Mineiro region (Romaria, Iraí de Minas, Grupiara and Douradoquara), with special attention given to the influence of the hydrographic network on the spatial distribution of the disease. The properties sampled (68) for laboratory and epidemiological analysis (questionnaire) were also georeferenced. The risk factors were analyzed using the ArcGIS 10.1 program. The animals were submitted to immunodiagnostic tests (enzyme-linked immunosorbent assay and immunoblot) for the diagnosis of bovine cysticercosis. After confirming the disease focus properties, the spatial distribution of the cases was analyzed in relation to the watershed of the region. The positive results for bovine cysticercosis on the properties of the municipalities of Romaria and Iraí de Minas were grouped together, which was a significant result $(\mathrm{p}<0.01)$. Although the positive results for bovine cysticercosis in the municipalities of Grupiara and Douradoquara were randomly distributed $(\mathrm{p}=0.27)$, the risk factor that proved to be statistically significant in the regression analysis for cysticercosis transmission was the water source from the river/ stream. From the analysis of the map based on the hydrography of the region, it can be observed that for the distribution of positive cases for bovine cysticercosis in the properties, the main risk factor was the interference of the rivers and their tributaries that fed the municipalities sampled. This study allowed the identification of the prevalence of the taeniasis-cysticercosis complex in the properties of the sampled municipalities $(53.84 \%$ in Romaria, $45.45 \%$ in Grupiara, $37.03 \%$ in Iraí de Minas and $35.29 \%$ in Douradoquara). The results from this study will help in the prevention and control of this zoonosis in the researched areas.
\end{abstract}

Key words: Bovine cysticercosis. Risk factors. Spatial distribution. Hydrography.

\section{Resumo}

A cisticercose acomete aos bovinos, que desenvolvem a larva da Taenia saginata, a partir da ingestão de seus ovos que são liberados pelos seres humanos. É uma parasitose que tem distribuição mundial. $\mathrm{O}$ uso do geoprocessamento possibilita melhor definição de áreas endêmicas e das populações sob

${ }^{1}$ Médica Veterinária, Discente do Curso de Doutorado em Medicina Veterinária, Universidade Federal de Viçosa, UFV, Viçosa, MG, Brasil. E-mail: camillatsd@yahoo.com.br

${ }^{2}$ Médicos Veterinários, Profs. Drs., Dept ${ }^{\circ}$ de Veterinária, UFV, Viçosa, MG, Brasil. E-mail: pintopsa@ufv.br; paula@ufv.br

${ }_{3}^{3}$ Médicos Veterinários, Drs., UFV, Viçosa, MG, Brasil. E-mail: leticiaafs@gmail.com; tatyvetoli@hotmail.com; ecanieto@gmail.com

* Author for correspondence

Received: Aug. 26, 2017 - Approved: Oct. 24, 2017 
diferentes níveis de risco, criando base para programas de controle específicos para cada sistema de criação agropecuária. O objetivo deste trabalho foi avaliar a situação epidemiológica da cisticercose bovina, em propriedades de quatro municípios da região do Triângulo Mineiro (Romaria, Iraí de Minas, Grupiara e Douradoquara), com especial atenção sobre a influência da rede hidrográfica na distribuição espacial da doença. As propriedades amostradas (68) para a análise laboratorial e epidemiológica (questionário) também foram georreferenciadas e realizada a análise dos fatores de risco com o uso do programa ArcGIS 10.1. Os animais foram submetidos a testes de imunodiagnóstico (ELISA E IMMUNOBLOT) para diagnóstico da cisticercose bovina e após a confirmação das propriedades foco da doença foi analisada a distribuição espacial dos casos em relação a bacia hidrográfica da região. Os resultados positivos para cisticercose bovina nas propriedades dos municípios de Romaria e Iraí de Minas mostraram-se agrupados, resultado esse significante $(p<0,01)$. Enquanto que os resultados positivos para cisticercose bovina nos municípios de Grupiara e Douradoquara mostraram-se aleatórios $(\mathrm{p}=0,27)$. $\mathrm{O}$ fator de risco que se mostrou estatisticamente significante na análise de regressão para a transmissão da cisticercose foi a fonte de água proveniente de rio/ribeirão. A partir da análise do mapa com base na hidrografia da região pode-se observar que a distribuição, dos casos positivos para cisticercose bovina nas propriedades, apresentou como principal fator de risco a interferência dos rios e seus afluentes que banham os municípios amostrados. Esse estudo permitiu a identificação da prevalência do complexo teníase-cisticercose nas propriedades dos municípios amostrados (53,84\% em Romaria, 45,45\% em Grupiara, 37,03\% em Iraí de Minas e 35,29\% em Douradoquara) e os resultados permitirão auxiliar na prevenção e no controle dessa zoonose nas áreas pesquisadas.

Palavras-chave: Cisticercose bovina. Fatores de risco. Distribuição especial. Hidrografia.

\section{Introduction}

Bovine cysticercosis composes the complex taeniasis-cysticercosis (CTC), a group of diseases reported among the most prevalent zoonoses in slaughterhouses of Brazil, with prevalence rates ranging from 1.70 to $7.39 \%$. Bovine cysticercosis is related to significant economic losses for the country due to the partial or total rejection of the carcasses of infected cattle. (SOUZA et al., 2007). In addition, cysticercosis represents a public health risk because humans acts as the definitive hosts of T. saginata (FLISSER et al., 2005).

Since there are few field studies and only scattered information is available regarding the prevalence of cysticercosis, determining the geographical distribution and risk factors of this zoonosis in Brazil is important. Some studies have been carried out to develop new diagnostic methods that can improve the precise identification of human and animal cases by instrumenting the control measures (SILVA et al., 2015). Recently, spatial tools have been used in CTC research and helped identify areas where there is a greater prevalence of the disease (ALLEPUZ et al., 2009; CASSINI et al, 2014). Dutra et al. (2012) used geoprocessing as a resource to estimate the prevalence of bovine cysticercosis in Brazilian states and municipalities using data obtained from slaughterhouses that were inspected by the Federal Inspection Service. This study made it possible to generate an epidemiological map and identify a prevalence of bovine cysticercosis of $1.05 \%$ for the whole country, and the Southeast was the region that presented the most cases.

In this manner, geoprocessing is a set of techniques for the collection, treatment and exhibition of information that is referenced in a determined geographic space, and it can be distinguished into the use of remote sensing techniques, scanning data, automating cartographic tasks, and using both a Global Positioning System (GPS) and System of Geographic Information (SIG) (HINO et al., 2006). This set of techniques has become an important tool in the control of endemic diseases by subsidizing epidemiologic studies and allowing the determination of the prevalence of diseases or the delimitation of areas of risks via the integrated analysis of epidemiologic and environmental data; the techniques have also been used as measures for preventing and controlling zoonoses, thus allowing decision-making and the formation of public health 
policies (CASSINI et al, 2014). Geoprocessing also enables the better definition of endemic areas of animal diseases and the populations that are at a greater risk, thereby guiding specific actions in sanitary programs that involve farming (FONSECA et al., 2005).

The detailed investigation of positive farms located in areas of higher prevalence of CTC can help identify routes by which tapeworm eggs are introduced into bovine herds as well as the risk factors associated with the maintenance and dissemination of bovine cysticercosis, which can help elucidate the distribution and clustering of cases of farms with the disease (CASSINI et al, 2014).

In addition, the use of pastures and contaminated water and the presence of people with taeniasis have been reported as the main routes of introduction for cysticercosis in bovine herds (EUROPEAN COMMISSION, 2000).

Thus, the objective of this research was to characterize the profile of spatial distribution and the main risk factors associated with bovine cysticercosis on rural properties in four municipalities in the region of the Triângulo Mineiro, Brazil.

\section{Material and Methods}

\section{Characterization of the studied area}

The survey was developed in the municipalities Iraí de Minas, Romaria, Grupiara and Douradoquara, which are located in the Mesoregion Triângulo Mineiro/Alto Paranaíba in the microregion of Patrocínio, state of Minas Gerais. The municipalities cover a total land area of $1,269.84 \mathrm{~km}^{2}$, which has an average demographic density of 10 inhabitants $\mathrm{km}^{2}$, an average GDP of R $\$ 64,980.75$ and a medium human development index of 0.71 (IBGE, 2013). The total population of the four municipalities is estimated at 16,454 inhabitants, and the majority $(82 \%)$ is located in urban areas (IBGE, 2013). The predominant vegetation in this region is the biome.
It has a tropical climate, with average temperatures between $17^{\circ} \mathrm{C}$ and $23^{\circ} \mathrm{C}$ and an annual thermal amplitude* between $7^{\circ} \mathrm{C}$ and $9^{\circ} \mathrm{C}$. The rainfall behavior is characterized by a dry and cold winter, with a low intensity rainfall and a hot and rainy summer. The average altitude ranges from 800 to 1200 meters, with a flat and smooth relief. It is in the watershed of the Paranaíba river (IGA, 2015). The main economic activities are based on cattle raising and agriculture (IBGE, 2013).

In the sampled properties, in $58.52 \%$ of them, the type of breeding was milk and cut (38.23\% milk and $13.23 \%$ cut). The intended purpose of most animals $(85.29 \%)$ was breeding, rearing and fattening. Animals of crossed races and Nelore predominated. In all properties, cattle had pasture-based feed, such as Brachiária and Panicum, and they received some type of supplementation in the dry period. The breeding system was extensive in most properties.

\section{Delineation}

To calculate the number of properties to be investigated, the following parameters were used: a disease prevalence estimated at 5\% (ALMEIDA et al., 2006; MOREIRA et al., 2002) and a significance level of 5\% calculated in the EpiInfo version 3.5.1 program (WHO, 2008). Based on these values, a sample size of 68 properties was obtained, and they were selected by a simple random sampling process by drawing lots from the 671 total properties in the four municipalities' counties. Additionally, the sample number of cattle was determined by the number of animals existing on the property: for a property with up to 20 animals, all of the animals were collected; for a property with between 21 and 200 animals, 20 were collected; and for a property with more than 201 animals, $10 \%$ of the total was collected.

At the properties, drawn blood samples from cattle were collected by means of a puncture of the jugular vein. Four hundred thirty-three samples were collected in Iraí de Minas, 191 samples in 
Romaria, 172 samples in Grupiara and 206 samples in Douradoquara (Table 1). These samples were centrifuged at 2,249 rpm (905 g). The sera were stored individually in microtubes at $-20^{\circ} \mathrm{C}$. These sera samples were submitted to an ELISA test with screening, in triplicate, for the diagnosis of cysticercosis (SILVA et al., 2015). The suspected cases (positive result by ELISA) were submitted to immunoblot for confirmation (MONTEIRO et al., 2006).

Table 1. Number of animals that were examined and tested positive for bovine cysticercosis according to the municipalities surveyed in the sponsor microregion.

\begin{tabular}{ccc}
\hline Municipalities & Number of animals examined & Number of positive animals \\
\hline Iraí de Minas & 433 & 21 \\
Romaria & 191 & 11 \\
Grupiara & 172 & 07 \\
Douradoquara & 206 & 08 \\
\hline Total & $\mathbf{1 0 0 2}$ & $\mathbf{4 7}$ \\
\hline
\end{tabular}

\section{Laboratory tests}

In the ELISA, polystyrene plates were sensitized with the diluted antigens $(40 \mu \mathrm{g} / \mathrm{ml})$ in $0.5 \mathrm{M}$ carbonate-bicarbonate buffer at $\mathrm{pH} 9.6$ after blocking the reactive sites (5\% skim milk in PBS $\mathrm{pH}$ 7.4), both for $1 \mathrm{~h}$ at $37^{\circ} \mathrm{C}$. Serum samples were diluted $1: 100$ in $1 \%$ skim milk in PBS at $\mathrm{pH}$ 7.4, were added in triplicate to the plates and incubated for $30 \mathrm{~min}$ at $37^{\circ} \mathrm{C}$. Then, the anti-bovine $\mathrm{IgG}$ conjugate A-5295 at a 1:1250 dilution (Sigma Chemical Co., St. Louis, MO, USA) was added, and the incubation procedure was repeated. After each incubation step, three washes of five minutes each were performed in saline containing $0.05 \%$ Tween-20 to remove excess reagents. The final step consisted of developing the reaction with OPD (phenylenediamine o-dihydrochloride) (0.1\%) and $0.003 \% \mathrm{H}_{2} \mathrm{O}_{2}$ solution in $0.2 \mathrm{M}$ citrate-phosphate buffer at $\mathrm{pH} 5.0$ for an incubation period of $5 \mathrm{~min}$. The reaction was quenched with $4 \mathrm{~N}_{2} \mathrm{SO}_{4}$. The readings were performed in a spectrophotometer at $492 \mathrm{~nm}$. The results were obtained at optical densities. The amount of reagents applied to the plate was $100 \mu \mathrm{L}$, except for the blocking solution, which was applied at $200 \mu \mathrm{L}$. In each plate, two negative control sera and one positive control serum were added to calculate the cut-off point and for plaque correction. To determine the positivity and negativity of each sample, cut-off points were calculated, defined as the mean optical densities of the reactions obtained with the negative control sera plus two standard deviations.

After electrophoresis, according to the methodology described by Towbin et al. (1979), the membranes were separated into 3-mm-wide strips to perform the immunoblot. These strips were discolored and washed three times in saline $(0.15 \mathrm{M} \mathrm{NaCl})$ containing $0.05 \%$ Tween-20; they were then treated with $5 \%$ blocking solution (skim milk) dissolved in Tris-saline (Trishydroxymethylaminoethane $10 \mathrm{mM}$ and $0.15 \mathrm{M}$ $\mathrm{NaCl}, \mathrm{pH}$ 7.4) and heated to $90^{\circ} \mathrm{C}$. Next, they were filtered on filter paper and held for one hour under slow stirring at room temperature. Serum samples were added at a dilution of 1:100 in skimmed milk with $1 \%$ Tris-saline ( $\mathrm{pH} 7.4$ ) for $1 \mathrm{~h}$. The strips were washed with $0.05 \%$ Tween-20 in Tris-saline (pH 7.4) six times for five minutes each. Then, the anti-bovine IgG conjugate A-5295 at the 1:2000 dilution (Sigma Chemical Co., St. Louis, MO, USA) was added for $2 \mathrm{~h}$. The washing procedures were repeated. Reactions were revealed with a chromogen solution (Diaminobenzidine $5 \mathrm{mg}$ per $30 \mathrm{~mL}, 0.15 \% \mathrm{H} 2 \mathrm{O} 2$ in PBS $\mathrm{pH}$ 7.2) for $2 \mathrm{~min}$, 
showing the reactive peptides in each strip. The reaction was then quenched with distilled water, and the strips were dried on filter paper. Reagents were added in $1 \mathrm{~mL}$ volume per well channel. The whole test was performed on an oscillating table, with constant and slow stirring, and at room temperature. In both tests (ELISA and immunoblot), the total antigen of $T$. crassiceps was used at a concentration of $6 \mu \mathrm{g} / \mathrm{mm}$, as recommended by Pinto et al. (2001).

\section{Data analysis}

The associated factors were assessed from information obtained by administering questionnaires at the properties visited; the questionnaires had previously been tested and sought information related to the system of animal husbandry and the source and use of water. We considered the following variables: positive property for bovine cysticercosis, source of water supplied to the animals, type of animal husbandry, and existence of a dam in the municipality.

Using the program SPSS 17.0 (MAROCO, 2011), statistical analysis was performed according to the positive results found for the disease on the sampled properties and the questionnaire, i.e., a property on which at least one animal was diagnosed as positive for the disease. First, a simple binary logistic regression analysis was performed, considering $\mathrm{p}<0.20$. The significant variables were subjected to multivariate binary logistic regression using the Backward method, with LR, considering $\mathrm{p}$ $<0.05$, serving as the basis for calculating the Odds Ratio* (RC), with a 95\% confidence interval.

All of the properties sampled were georeferenced using the GPS receptor (Global Positioning System) Garmin model vista $\mathrm{HCx}$, configured in the system of projection UTM (Universal Transverse Mercator), Datum SAD 69. The points were stored in the program TrackMaker ${ }^{\circledR}$ release 13.9 for the subsequent mapping of the region studied and for analyzing the distribution of the risk factors associated with transmission of the disease.
For the production and manipulation of spatial data, the ArcINFO platform was used (ArcGISESRI), adopting the holistic model of a functional Geographical Information System based on the acquisition of maps, spatial data storage (GIS Storage) and generation of information on thematic maps. The spatial analysis was performed using the program ArcGIS 10.1 to construct maps and the hydrographic networks in which the municipalities were included according to the positive and negative diagnoses for bovine cysticercosis among the properties sampled. According to the analysis of the data patterns of positivity of the disease, the municipalities were separated into two groups of two municipalities each. It was used as a default for the average nearest neighbor, using the Euclidean distance method with a confidence interval of $99 \%$.

\section{Ethics Committee}

This research was approved by the Ethics Committee in Research with Animals (Process 26/2013 Process), which is linked to the Federal University of Viçosa.

\section{Results and Discussion}

In this study, no significant difference was observed in relation to the type of rearing that was performed on the properties. Dorny et al. (2000), when comparing serum prevalence among dairy herds and herds of cut, did not find that the type of breeding had any influence on the prevalence of bovine cysticercosis. However, the cattle breeding regime, coupled with the low socioeconomic and cultural level of the population and the precarious health conditions, contributes to the contamination of pastures and maintains a direct relation with the occurrence of cysticercosis among cattle (SCANDRETT et al. 2009).

In addition, animals having free access to pastures (an extensive system) is a characteristic of most of the properties sampled, which favors the 
transmission of cysticercosis. Pathogens such as $T$. saginata can be disseminated indiscriminately, thus exposing bovine populations to infection (OWEN, 2005).

The laboratory results indicated that the properties of the municipality of Romaria were those that presented more assertiveness for the agent, at $53.84 \%$, followed by the municipalities of Grupiara, at $45.45 \%$, Iraí de Minas, at $37.03 \%$, and Douradoquara, at $35.29 \%$. The prevalence identified for bovine cysticercosis was $4.69 \%$ in the sampled region.

The positive results for bovine cysticercosis on the properties of the municipalities of Romaria and Iraí de Minas showed clusters, which was a significant result $(\mathrm{p}<0.01)$, because according to the $\mathrm{z}$-score of -5.49 , which indicates the spatial pattern, there is a probability of less than $1 \%$ that this grouped pattern may have been due to chance. Although positive results were found for bovine cysticercosis in the municipalities of Grupiara and Douradoquara, they presented a random spatial distribution $(p=0.28)$ because according to the $\mathrm{z}$-score of -1.08 , the pattern found may have been due to chance.

From the analysis of the map of the hydrography of the region (Figure 1), the occurrence of properties that tested positive for bovine cysticercosis presented clusters in the municipalities of Romaria (C) and Iraí de Minas (D), thus demonstrating the possibility of the transmission of this parasitosis via the interference of rivers and their tributaries that feed these two municipalities. In the regression analysis, which also verified that the number of properties with bovine positive diagnosis for bovine cysticercosis was significantly higher when the water used for watering the livestock was derived from a river/stream compared to other sources (Table 2), these properties are 6.0 times more likely to have bovine cysticercosis than are the properties that used other water sources, such as a public supply, mine/spring or others (cistern or lagoon). Oliveira et al. (2011) found that approximately $80 \%$ of the municipalities in the State of Alagoas, which exhibited higher percentages of carcasses condemned by cysticercosis, are intersected by the rivers Paraíba and Mundaú, which were considered an important determining factor for the occurrence of the disease in the Brazilian region.

The municipality of Romaria, where there was a greater prevalence of the disease, is devoid of any sewage treatment system, and the same is found for the remaining sampled municipalities. Fonseca and Spíndola (2013) reported that many cattle can eventually be contaminated with cysticercosis parasites at considerable distances from the contaminating* source due to a small number of human carriers, a possible factor related to rainfall that flows down hillsides and from watercourses. This scenario can be repeated in different regions of Brazil, where only $37.50 \%$ of the sewage generated receives treatment. Although more than half of all Brazilian municipalities have a sewage network, this does not ensure the proper extension of the network, quality of care, number of households served or sewage treatment (IBGE, 2012). 
Figure 1. Spatial distribution of the bovine cysticercosis cases in the municipalities of Grupiara (A), Douradoquara (B), Romaria (C) and Iraí de Minas (D) and hydrography of the region: Dam of Emborcação (1), River Bagagem (2), Stream Santa Fé (3), River Perdizes (4), River Dourados (5) and Dam of Nova Ponte (6).

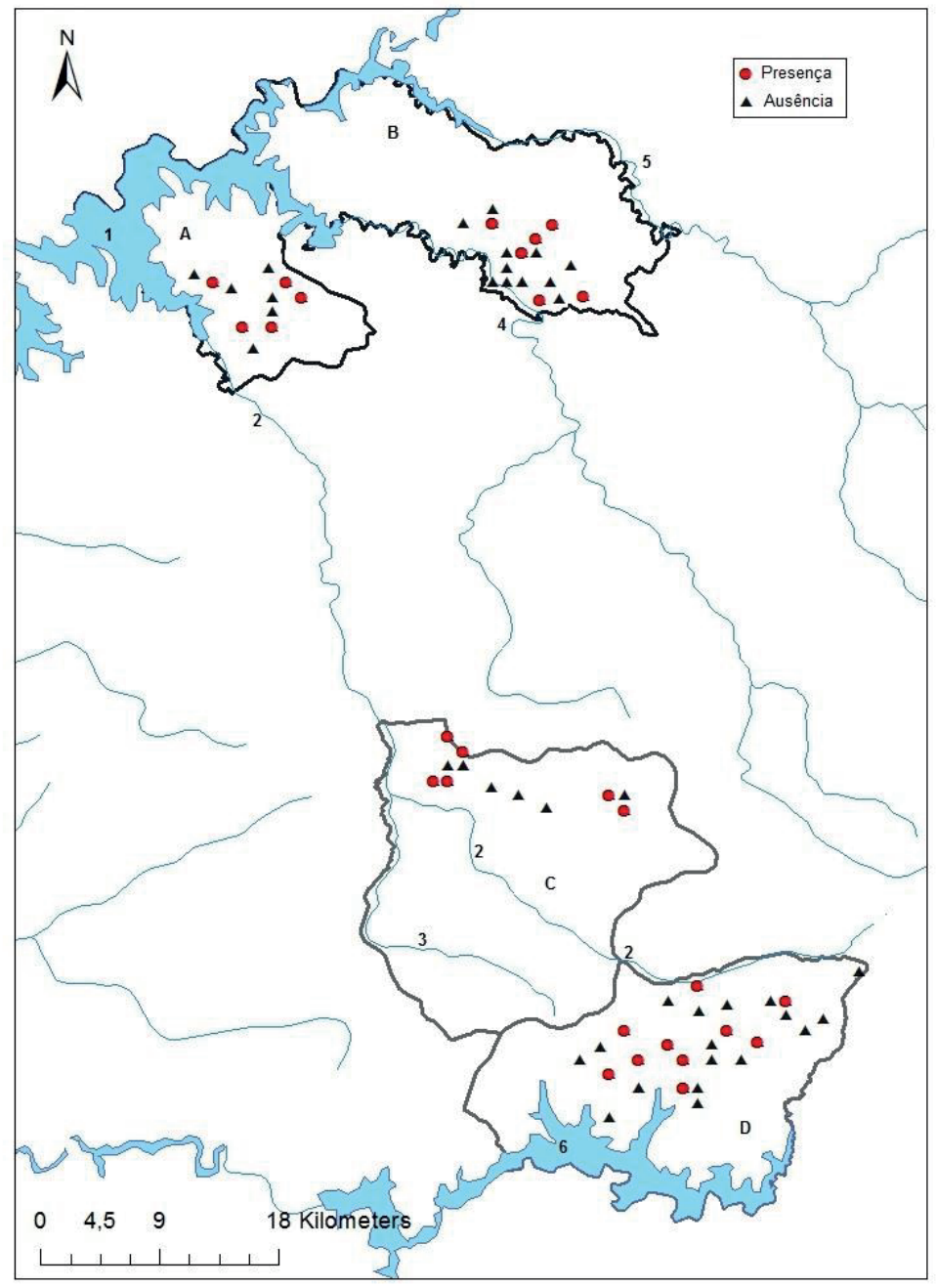

Table 2. Multivariate logistic regression analysis of the risk factors associated with the occurrence of bovine cysticercosis.

\begin{tabular}{ccccc}
\hline Risk Factor & Category & RC & p-value & IC \\
\hline Water Source & River/Stream & 6.00 & 0.02 & $1.34-26.80$ \\
& Mine/Spring* & 2.66 & 0.21 & $0.56-12.55$ \\
& Other & 1.33 & 0.78 & $0.17-10.25$ \\
& Public Supply & Reference & & \\
\hline
\end{tabular}

*Reference value for the calculation of the Razão de Chances* (RC). For the calculation of the RC, the lesser risk factor was determined, attributing for such risk at 1.00; later, the value of the variables was calculated, taking as reference the less risk variable. $* \mathrm{IC}=$ Interval of confidence $(95 \%)$. 
In addition, the presence of dams in the municipalities can contribute to the spread of this disease, although in the regression analysis, this variable showed no statistically significant difference. In the city of Iraí de Minas, the construction of the dam of Nova Ponte (6) resulted in the overflow of an area of $57,70 \mathrm{~km}^{2}(19.24 \%$ of the area of the municipality); in Grupiara and Douradoquara, the dam of Emborcação (1) was responsible for the overflow of a $77.43 \mathrm{~km}^{2}$ area (67.65\% of the area of the municipality) and 46,68 $\mathrm{km}^{2}(17.50 \%$ of the area of the municipality), respectively (FERREIRA et al., 2008). Studies have demonstrated that flooding of the pastures was an important factor for the propagation of cysticercosis on the properties (BOONE et al., 2007; ALLEPUZ et al., 2009) and that the animals with free access to the water of the contaminated surfaces (rivers, lakes, canals) were subjected to contamination by this parasitosis (BOONE et al., 2007).

Another study conducted in the south, southeast and Goiás State Metropolitan area showed a prevalence of bovine cysticercosis indices that was similar to that found in the sampled region, which can be attributed to the fact that these regions are being fed by the Lake of São Simão and the rivers Paranaíba, Claro, dos Bois and others of lesser extent. According to Mariano-da-Silva et al. (2012), these rivers receive urban sewers along their courses. At the time of flooding, which can be frequent, there is often flooding of grazing areas, which contaminates the same and allows animals to consume contaminated water. Further, the municipalities of Grupiara and Douradoquara, which were sampled in this study, are also fed by the river Paranaíba, and the pastures of their properties are affected by constant floods, thus allowing the transmission of this cattle disease to these municipalities.

Other studies carried out in European countries identified the water supply as a precursor of bovine cysticercosis in $41.8 \%$ of the properties analyzed. In addition to citing sources of water as risk factors, they considered that access to rivers that carry wastewater from sewage treatment stations or flooded pastures is among the main potential sources of infection from cysticercosis to animals (ALLEPUZ et al., 2009; CALVO-ARTAVIA et al., 2013). These features have also been identified in the region of the properties sampled.

\section{Conclusion}

Risk analysis along with the mapping and spatial analysis of the data made it possible to verify that the water supply of the properties was the primary risk factor in the region studied, configuring as disseminating bovine cysticercosis. The system of extensive breeding, to which bovines of the sampled properties were submitted, allows these animals access to water sources of unknown quality, such as a river/stream. Furthermore, the existence of dams that flood bigger areas of pastures of the properties makes it possible for the animals to come into contact with contaminated waters and fodder plants, which explains how this is the main route of contamination of the properties with bovine cysticercosis in the four municipalities investigated.

\section{Acknowledgements}

We thank the Instituto Mineiro de Agropecuária for their logistic cooperation, and Fapemig (Fundação de Amparo à Pesquisa de Minas Gerais), CNPq (Conselho Nacional de Desenvolvimento Científico e Tecnológico) and CAPES (Coordenação de Aperfeiçoamento de Pessoal de Nível Superior) for financial support.

\section{References}

ALLEPUZ, A.; NAPP, S.; PICADO, A.; ALBA, A.; PANADES, J.; DOMINGO, M.; CASAL, J. Descriptive and spatial epidemiology of bovine cysticercosis in NorthEastern Spain (Catalonia). Veterinary Parasitology, Amsterdam, v. 159, n. 1, p.43-48, 2009. 
ALMEIDA, L. P.; REIS, D. O.; MOREIRA, M. D.; PALMEIRA, S. B. S. Cisticercose em bovinos procedentes de Minas Gerais e abatidos em frigoríficos de Uberlândia-MG, no período de 1997 a 2001. Higiene Alimentar, Mirandópolis, v. 2, n. 139, p. 40-43, 2006.

BOONE, I.; THYS, E.; MARCOTTY, T.; BORCHGRAVE, J. D.; DUCHEYNE, E.; DORNY, P. Distribution and risk factors of bovine cysticercosis in Belgian dairy and mixed herds. Preventive Veterinary Medicine, Amsterdam, v. 82, n. 1-2, p. 1-11, 2007.

CALVO-ARTAVIA, F. F.; NIELSEN, L. R.; DAHL, J.; CLAUSEN, D. M.; ALBAN, L. Occurrence and factors associated with bovine cysticercosis recorded in cattle at meat inspection in Denmark in 2004-2011. Preventive Veterinary Medicine, Amsterdam, v. 110, n. 2, p. 177182, 2013.

CASSINI, R.; MULATTI, P.; ZANARDELLO, C.; SIMONATO, G.; SIGNORINI, M.; CAZZIN, S.; TAMBALO, P. G.; COBIANCHI, M.; PIETROBELLI, M.; CAPELLI, G. Retrospective and spatial analysis tools for integrated surveillance of cystic echinococcosis and bovine cysticercosis in hypo-endemic areas. Geospatial Health, Pavia, v. 8, n. 2, p. 509-515, 2014.

DORNY, P.; VERCAMMEN, F.; BRANDT, J.; VANSTEENKISTE, W.; BERKVENS, D.; GEEERTS, S. Sero-epideiological study of Taenia saginata cysticercosis in Belgian cattle. Veterinary Parasitology, Amsterdam, v. 88, n. 1-2, p. 43-49, 2000.

DUTRA, L. H.; GIROTTO, A.; VIEIRA, R. F. C.; WISCHRAL, T. S.; VIEIRA, J.; ANGIROLAMO, A. F.; MARQUÊS, F. A. C.; HEADLEY, S. A.; VIDOTTO, O. A prevalência e epidemiologia espacial da cisticercose em bovinos abatidos no Brasil. Semina: Ciências Agrárias, Londrina, v. 33, n. 5, p. 1887-1896, 2012.

EUROPEAN COMISSION. Opinion of the scientific committee on veterinary measures relating to public health on the control of taeniasis/cysticercosis in man and animals. Bruxelas: Directorate $\mathrm{C}-$ Scientific Opinions, 2000. Available at: <http://ec.europa.eu/food/fs/sc/scv/ out36_en.pdf $>$. Accessed at: 14 mar. 2015.

FERREIRA, V. V. M.; MARTINEZ, C. B.; VERSIANI, B. R. Metodologia para estimação de externalidades agropecuárias decorrentes da construção de reservatórios. Engenharia Sanitária Ambiental, Rio de Janeiro, v. 13, n. 1, p. 29-37, 2008.

FLISSER, A.; CORREA, D.; AVILA, G.; MARAVILLA, P. Biology of Taenia solium, Taenia saginata and Taenia saginata asiática. In: MURRELL, K. D. (Ed.). Manual on Taeniasis and Cysticercosis in man and animals: detection, treatment and prevention. WHO/FAO/OIE, Paris, 2005. p. 1-9.
FONSECA, A. H.; PEREIRA, M. J. S.; GÓES, M. H. de B.; SILVA, J. X. Distribuição espaço-temporal de Boophilus microplus (Acari: Ixodidae) analisada por geoprocessamento, no município de Seropédica, estado do Rio de Janeiro, Brasil. Revista Brasileira de Parasitologia Veterinária, Jaboticabal, v. 14, n. 4, p. 167 172, 2005.

FONSECA, J. M.; SPÍNDOLA, T. A cisticercose bovina identificada na região autônoma da Madeira: um problema de saúde animal e de saúde pública. Portugal: Vetbiblios, 2013. Disponível em: <http://www.vetbiblios. pt/ARTIGOS_TECNICOS/Zoonoses/Cisticercose_ bovina_identificada_na_RAM.pdf $>$. Acesso em: $15 \mathrm{dez}$. 2015.

HINO, P.; VILLA, T. C. S.; SASSAKI, C. M.; NOGUEIRA, J. de A.; SANTOS, C. B. dos. Geoprocessamento aplicado à área da saúde. Revista Latino-Americana de Enfermagem, Ribeirão Preto, v. 14, n. 6, p. 939-943, 2006.

INSTITUTO BRASILEIRO DE GEOGRAFIA E ESTATÍSTICA - IBGE. Cidades. Brasil: IBGE, 2013. Disponível em: $<$ http://cidades.ibge.gov.br/xtras/home. php>. Acesso em: 19 nov. 2013.

IDS 2012: Brasil avança rumo ao desenvolvimento sustentável, mas ainda tem muitos desafios a enfrentar. Brasil: IBGE, 2012.

INSTITUTO DE GEOCIÊNCIAS APLICADAS - IGA. Mapas. Brasil: IGA, 2015. Disponível em: <http://icht. io.inf.br/mg_mapas/mapa/cgi/iga_comeco1024.htm>. Acesso em: 15 maio 2015.

MARIANO-DA-SILVA, S.; ROCHA, R. N.; OLIVEIRA, S. L.; COSTA NETTO, A. P. Bovine cysticersosis prevalence in the State of Goiás (Brazil). Agrarian, Dourados, v. 5, n. 16, p. 187-192, 2012.

MAROCO, J. Análise estatística com o SPSS Estatistics. In: ReportNumber. Introdução ao SPSS statistics. Pero Pinheiro: Rolo \& Filhos II, AS, 2011. p. 63-86.

MONTEIRO, L. L.; PINTO P. S. A.; DIAS F. S. Evaluation of the ELISA test for the antibody detection in catle naturally and experimentally infected with Cysticerccus bovis. Veterinary Parasitology, Amsterdam, v. 141, n. $3-4$, p. $260-63,2006$.

MOREIRA, M. D.; ALMEIDA, L. P.; REIS, D. O. Cisticercose bovina: um estudo com bovinos abatidos em matadouro municipal de Uberlândia, MG. Higiene Alimentar, Mirandópolis, v. 16, n. 100, p. 37-41, 2002.

OLIVEIRA, A. W.; OLIVEIRA, J. A. C.; BATISTA, T. G.; OLIVEIRA, E. R. A.; CAVALCANTI NETO, C. C.; ESPÍNDOLA FILHO, A. M. Estudo da prevalência da cisticercose bovina no estado de Alagoas. Acta Veterinaria Brasilica, Mossoró, v. 5, n. 1, p. 41-46, 2011. 
OWEN, I. L. Parasitic zoonoses in Papua New Guinea. Journal of Helminthology, Cambridge, v. 79, n. 1, p. 1-14, 2005.

PINTO, P. S. A.; VAZ, A. J.; NAKAMURA, P. M.; GERMANO, P. M. L. Immunoblot analysis using antigen from Taenia crassiceps cysticerci in the diagnosis of swine cysticercosis. Boletin Chileno de Parasitologia, Santiago, v. 56, n. 1-2, p. 36-42, 2001.

SCANDRETT, B.; PARKER, S.; FORBES, L.; GAJADHAR, A.; DEKUMYOY, P.; WAIKAGUL, J.; HAINES, D. Distribution of Taenia saginata cysticerci in tissues of experimentally infected cattle. Veterinary Parasitology, Amsterdam, v. 164, n. 2-4, p. 223-231, 2009.

SILVA, L. F.; PINTO, P. S. A.; DUARTE, C. T. D.; SANTOS, T. O.; NIETO, E. C. A.; PEIXOTO, R. P. M. G. Desempenho do teste ELISA no diagnóstico da cisticercose em bovinos com diferentes antígenos e níveis de infecção. Semina: Ciências Agrárias, Londrina, v. 36, n. 3, p. 2013-2022, 2015.
SOUZA, V. K.; PESSÔA-SILVA, M. C.; MINOZZO, J. C.; THOMAZ-SOCCOL, V. Prevalência da cisticercose bovina no estado do Paraná, sul do Brasil: avaliação de 26.465 bovinos inspecionados no SIF 1710. Semina: Ciências Agrárias, Londrina, v. 28, n. 4, p. 675-684, 2007.

TOWBIN, H.; STAEHELIN, T.; GORDON, I. Electrophoretic transfer of proteins from polyacrylamide gels to nitrocellulose sheets: procedure and some applications. Proceedings of the National Academy of Sciences, Washington, v. 76, n. 9, p. 4350-4352, 1979.

WORLD HEALTH ORGANIZATION - WHO. EPI INFO. Database and statistics software for public health professonals. Centers for Disease Control and Prevention (CDC). Versão 3.5.1. Estados Unidos: WHO, 2008. 